TEC-0006

\title{
Comparison of Air Photo Lineations and Joint Patterns, Dartmoor, Southwest England
}

Judy Ehlen

May 1992

Approved for public release; distribution is unlimited.

U.S. Army Corps of Engineers

Topographic Engineering Center

Fort Belvoir, Virginia 22060-5546

US Army Corps

of Engineers

Topographic

Engineering Center

Destroy this report when no longer needed.

Do not return it to the originator.

The findings in this report are not to be construed as an official Department of the Army position unless so designated by other authorized documents.

The citation in this report of trade names of commercially available products does not constitute official endorsement or approval of the use of such products. 
TITLE

FIGURES

TABLES

iv

PREFACE

INTRODUCTION

THE STUDY AREA

DEFINITIONS

$\begin{array}{ll}\text { PROCEDURES } & 3\end{array}$

Field Methods $\quad 3$

Air Photo Analysis 3

Data Analysis $\quad 4$

$\begin{array}{lr}\text { RESULTS } & 9\end{array}$

$\begin{array}{ll}\text { Orientations } & 9\end{array}$

$\begin{array}{ll}\text { Spacing } & 11\end{array}$

COMPARISON OF LINEATIONS AND JOINT PATTERNS 13

$\begin{array}{ll}\text { Orientations } & 13\end{array}$

$\begin{array}{ll}\text { Spacing } & 14\end{array}$

$\begin{array}{ll}\text { CONCLUSIONS } & 15\end{array}$

REFERENCES 16 


\section{ILLUSTRATIONS}

FIGURE

1

2

3

4

5

6

7

$8 a$

$8 b$

9

$10 \mathrm{a}$

$10 \mathrm{~b}$
TITLE

PAGE

Location map showing Dartmoor, southwest England

A typical tor: Bonehill Rocks, eastern Dartmoor

2

1:24,000-scale photo mosaic with lineations

5

Digitized lineations from the 1:24,000-scale photo mosaic

6

Digitized lineations from the 1:50,000-scale photo mosaic

7

Computer-identified lineation set with typical lines of measurement

Rose diagram showing vertical joint orientations measured in the field

Rose diagram showing orientations of the 1:50,000-scale lineations

Rose diagram showing orientations of the 1:24,000-scale lineations

Histogram showing vertical joint spacing frequencies measured in the field

Histogram showing lineation spacing frequencies for the 1:50,000-scale lineations

Histogram showing lineation spacing frequencies for the $1: 24,000$-scale lineations

\section{TABLES}

TABLE

TITLE

PAGE

Prominent Trends for the Three Data Sets

Modal Spacing for the Three Data Sets 


\section{PREFACE}

This report was prepared under DA Project 4A161102B52C, Task AO, Work Unit 010, "Hyperspectral Research" in April and May 1991, under the supervision of Dr. J.N. Rinker, Chief, Remote Sensing Division; and of Mr. John Hansen, Director, Research Institute.

I gratefully acknowledge the helpful suggestions provided by Allan Dewall and Dr. Ann Benn, both of USATEC, in their reviews of this paper. I also wish to thank Dr. John Gerrard, University of Birmingham, Birmingham, England, for his advice, support and helpful comments throughout the duration of the work that has resulted in this paper.

Mr. Walter E. Boge was Director, and LTC John F. Olesak was Commander and Deputy Director of the Topographic Engineering Center at the time of publication of this report. 


\section{INTRODUCTION}

Many projects, such as siting repositories for toxic and nuclear waste; identifying potential routes for contamination and pollution from leaking repositories; locating and developing geothermal energy sources; locating groundwater sources and selecting sites for engineering structures, such as dams; require detailed information about surface and subsurface fracture patterns, preferably in three dimensions. Unfortunately, subsurface fracture data, typically obtained from bore holes and cores and along subterranean tunnels, is usually not collected in a manner that provides the detailed information needed to reconstruct a three-dimensional fracture network.

Prior to addressing the three-dimensional problem, controversy as to whether lineations identified on remotely-sensed imagery are related to fracture patterns identified on the ground must be settled. Study of two-dimensional fracture networks using remotely-sensed imagery could prove highly useful if such patterns could be directly related to similar data collected in the field. The purpose of this study is to determine if such a relationship exists.

Evidence of relations between lineations on air photos and fracture patterns identified from field work is contradictory. Segall and Pollard (1983) concluded that the same trends occurred on air photos and on the ground in granites of the Sierra Nevada, whereas Thorp (1967a, 1967b) and Mohammad (1986) found this is not so for Nigerian granites and Saudi Arabian limestone, respectively. Rinker (1974) showed that subsurface fracture patterns can be related to surface fracture patterns delineated on air photos in his attempt to locate subterranean caves in limestones. Brown (1961) strongly emphasized the need for caution in making conclusions about the relations between lineations identified on air photos and fractures identified by field work regardless of rock type.

Granitic rocks were selected for study because (1) they are relatively common, (2) their photo patterns are fairly well understood and are well documented (Belcher et al., 1951; Bandat, 1962; Way, 1973; Rinker and Corl, 1984; Gerrard, 1988), and (3) fracture patterns in granitic rocks are highly distinctive and are readily quantifiable, whether in the field or on air photos.

\section{THE STUDY AREA}

The area selected for study was the Dartmoor granite in southwest England, which covers approximately 625 square kilometers (see Figure 1). Dartmoor is the most significant highland in southern Britain, and forms a plateau that tilts gently to the southeast. Elevations range from 150 to 600 meters. Most of the outcrops are located on large rounded or domical hills and are called "tors" (see Figure 2). Weathering and erosion along major joints are responsible for the appearance of the landscape (Gerrard, 1974, 1978). The Dartmoor granite forms the easternmost boss of the Cornubian batholith, which is Carboniferous/Permian in age (about 285-295 Ma; Darbyshire and Shepherd, 1985). The strongly megacrystic biotite granites are highly peraluminous and are associated with important mineralization. Hydrothermal alteration is extensive.

\section{DEFINITIONS}

Joint: a fracture along which no discernible movement has occurred. Joints may be filled with secondary minerals, but this is uncommon on Dartmoor where most joints are open. 




Figure 1. Location map showing Dartmoor, southwest England



Figure 2. A typical tor: Bonehill Rocks, eastern Dartmoor 
Joint set: a group of joints each having the same (or very similar) orientation and dip. The members of a joint set are usually formed under the same conditions.

Joint spacing: the distance between successive joints in a given joint set, measured normal to the planes of the joints along a linear traverse of continuous outcrop.

Vertical joint: a joint that dips 70 degrees or more.

Primary joint: a long, usually open, tor-shape-controlling joint that typically cuts across other joint traces. No genetic connotation is implied by this term.

Lineation: a natural linear feature seen on remotely-sensed imagery. Lineations are usually straight, but long ones can be gently curved.

Lineation spacing: the distance between successive lineations, measured normal to the planes of the lineations along a linear traverse.

\section{PROCEDURES}

\section{Field methods}

Joint spacing and orientation measurements were made on 185 joint sets at 58 sample sites in the field. Approximately 7,000 joint spacing measurements were made. The sample sites were more often than not chosen because of outcrop size; large outcrops were required because only the larger outcrops contained enough joint sets and enough joints in each set to provide an adequate sample. Only natural outcrops were used; no measurements were taken in quarries because of the presence of blasting-induced fractures. Outcrop shape is usually controlled by at least three joint sets -- one horizontal set, one vertical set perpendicular to the face of the outcrop forming its sides, and a second vertical set parallel to and forming the face of the outcrop. An outcrop was selected for measurement if there were a minimum of 12 joints per set for each of these three sets.

Once an outcrop was selected, spacings between every joint in every set that had enough joints were measured. Joint spacing was measured in centimeters normal to the plane of the joint and is thus a true measure of the spacing between adjacent joints in a set. Measurements were usually made on continuous outcrops, and all joints in each selected set were measured, open or closed. Even spacings between tiny, hairline fractures were measured. Dip and strike were also measured using a Brunton compass.

\section{Air photo analysis}

1:50,000-scale air photos of Dartmoor, flown in August 1981, were obtained from the British Ministry of Defence, and 1:24,000-scale photos, flown in August 1975, were purchased from the Ordnance Survey in Southampton, England. The photos were laid as uncontrolled mosaics. The lineation overlays were done monoscopically, but were checked using a mirror stereoscope.

Lineations are relatively easy to identify on imagery: any natural linear feature constitutes a lineation. Lineations typically occur as dark- or light-toned lines that cross the terrain irregardless of topography. Tonal differences are in fact the key to identification. Lineation patterns consist of a series 
of parallel to subparallel lines of different lengths often crossed or intersected by similar patterns with different orientations, producing a two-dimensional network. Long, curved lineations are also common; such lineations typically occur singly. These lines may be actual fractures in bedrock surfaces, water lying in linear depressions (e.g. San Andreas Lake, south of San Francisco in California), long straight stream segments, or lines of trees or other vegetation (e.g. palm trees growing along the San Andreas Fault in the Coachella Valley, southern California). Many lineations consist of segments that may or may not be of the same type: a linear vegetation pattern, for instance, may continue as a straight stream segment or simply as a dark-toned line. Segments typically vary in length, and en echelon patterns are common.

Care must be taken, however, in determining whether a particular linear feature is natural or manmade. Most of Dartmoor, for instance, has at some time been enclosed and remains of walls, which are the typical field boundary, can appear very much like natural lineations. Stream courses on Dartmoor have been straightened over the centuries, particularly by tin miners, so one must look carefully to determine whether potential lineations are artificially-straightened streams or natural stream segments, i.e. true lineations. Leats, ditches providing water to mines, isolated farms, and nearby urban areas, can occasionally cause confusion as well. Leats are quite easy to distinguish, however, because sections that contour the topography are common.

All linear patterns were thus evaluated meticulously from different viewing angles and with different kinds and angles of illumination. All natural lineations that could be depicted on the overlays were delineated. Pen point size virtually controls the minimum length and spacing between lineations that can be depicted, as well as the number of closely-spaced lineations, and all such delineations are of course controlled by image scale. The lineations were not located in the field because of the difficulty in doing so. One lineation consists of multiple fractures on the ground, both horizontally and along the trace of the lineation. The lineations were checked against the air photos, however, and all were determined to be natural. The 1:24,000-scale photo mosaic and its lineation overlay are shown in Figure 3.

The individual lineations on the overlays and the granite boundary from the landform overlays were digitized using a Geographic Information System (GIS) called CAPIR (Computer-Assisted Photo Interpretation Research; Lukes, 1981). The bearing of each lineation relative to true north was calculated from the digitized coordinates. There are about 1,500 lineations on the 1:50,000-scale mosaic (see Figure 4) and 2,900 on the 1:24,000-scale mosaic (see Figure 5). The lineations were grouped by orientation in 5-degree increments (e.g. 72.5 to $77.5^{\circ}=75^{\circ}$ ) to match joint strikes measured in the field. Spacings between lineations in each 5-degree increment were measured interactively in meters on spatially distinct groups of lineations along a line normal to bearing. Two such lines of measurement are shown on Figure 6 . The lines of measurement were chosen so that the greatest number of lineation spacings were obtained in a straight line, as one would measure joint spacings on continuous outcrop. About 1,000 spacings were measured on the 1:50,000-scale mosaic, and about 1,700 on the 1:24,000-scale mosaic.

\section{Data analysis}

The variables used to compare and evaluate lineation and joint patterns were orientation, spacing, and scale. Rose diagrams to evaluate lineation and joint orientations were compared and analyzed visually. Frequency histograms and descriptive statistics were used to analyze and compare the lineation and joint spacings. The descriptive statistics calculated for each histogram were minimum, maximum, and mean spacings; mode; and the total number of joints. The frequency distributions were compared using the chi square test. 


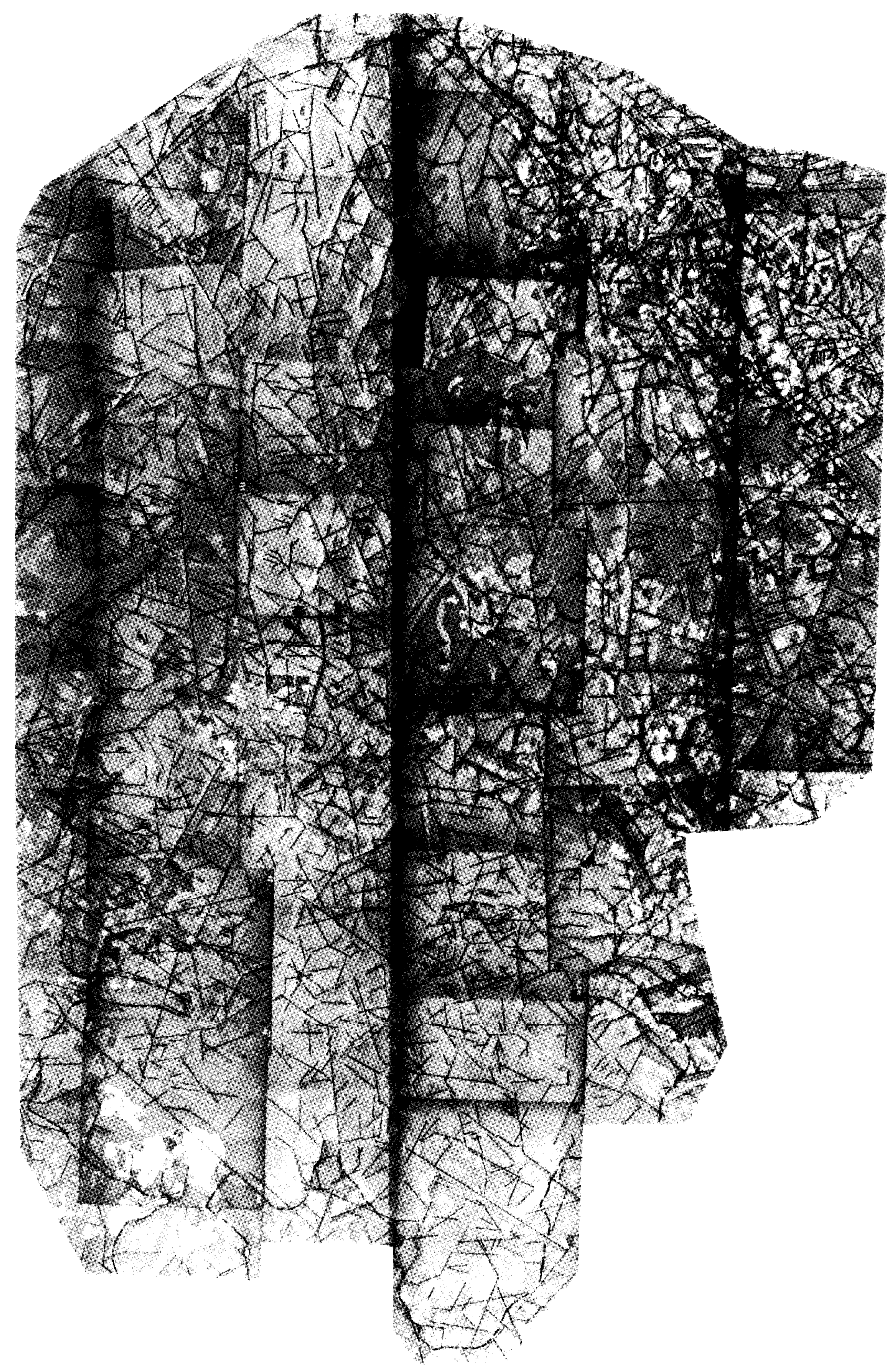

Figure 3. $1: 24,000$-scale photo mosaic with lineations 


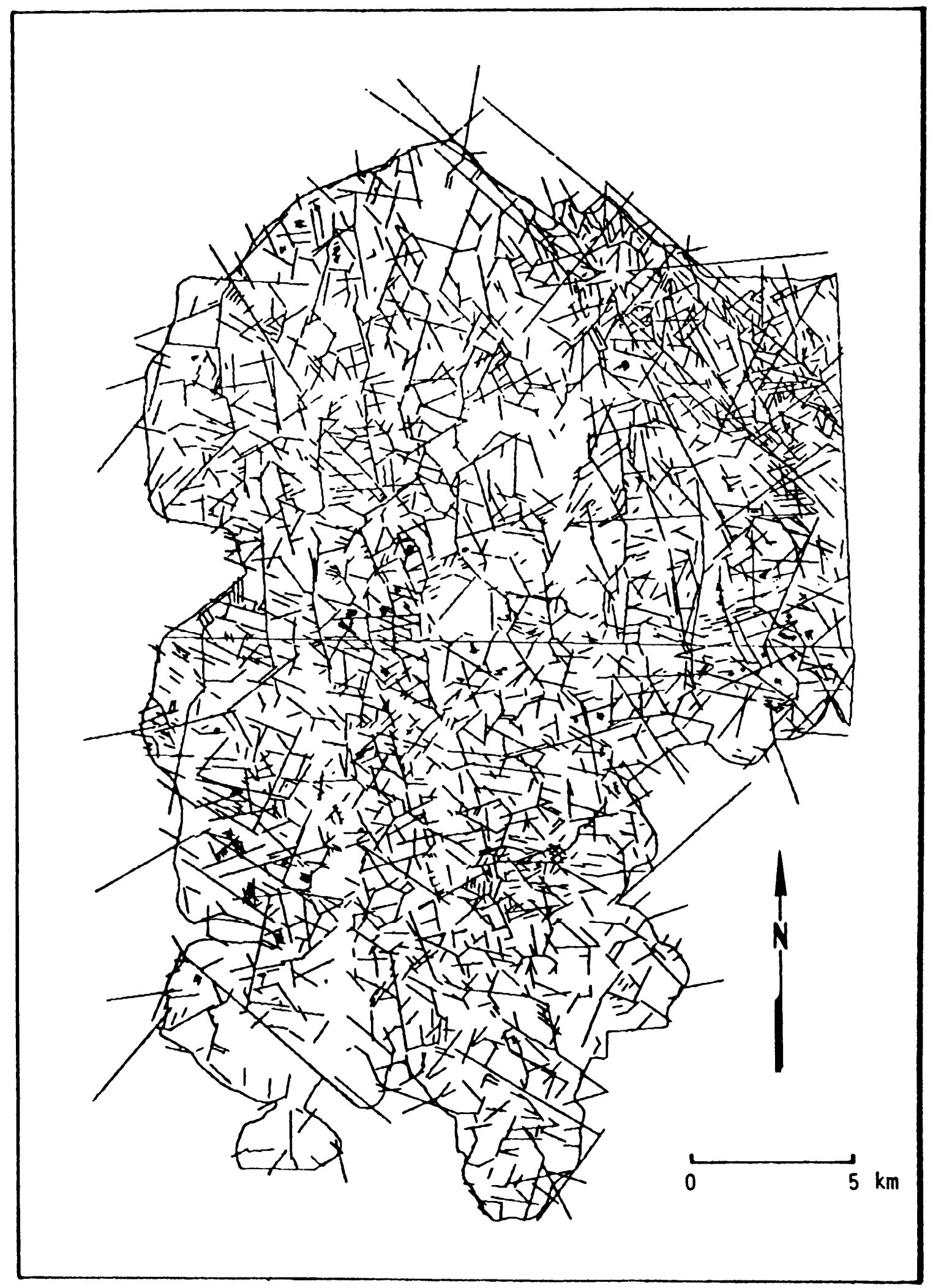

Figure 4. Digitized lineations from the 1:24,000-scale photo mosaic 


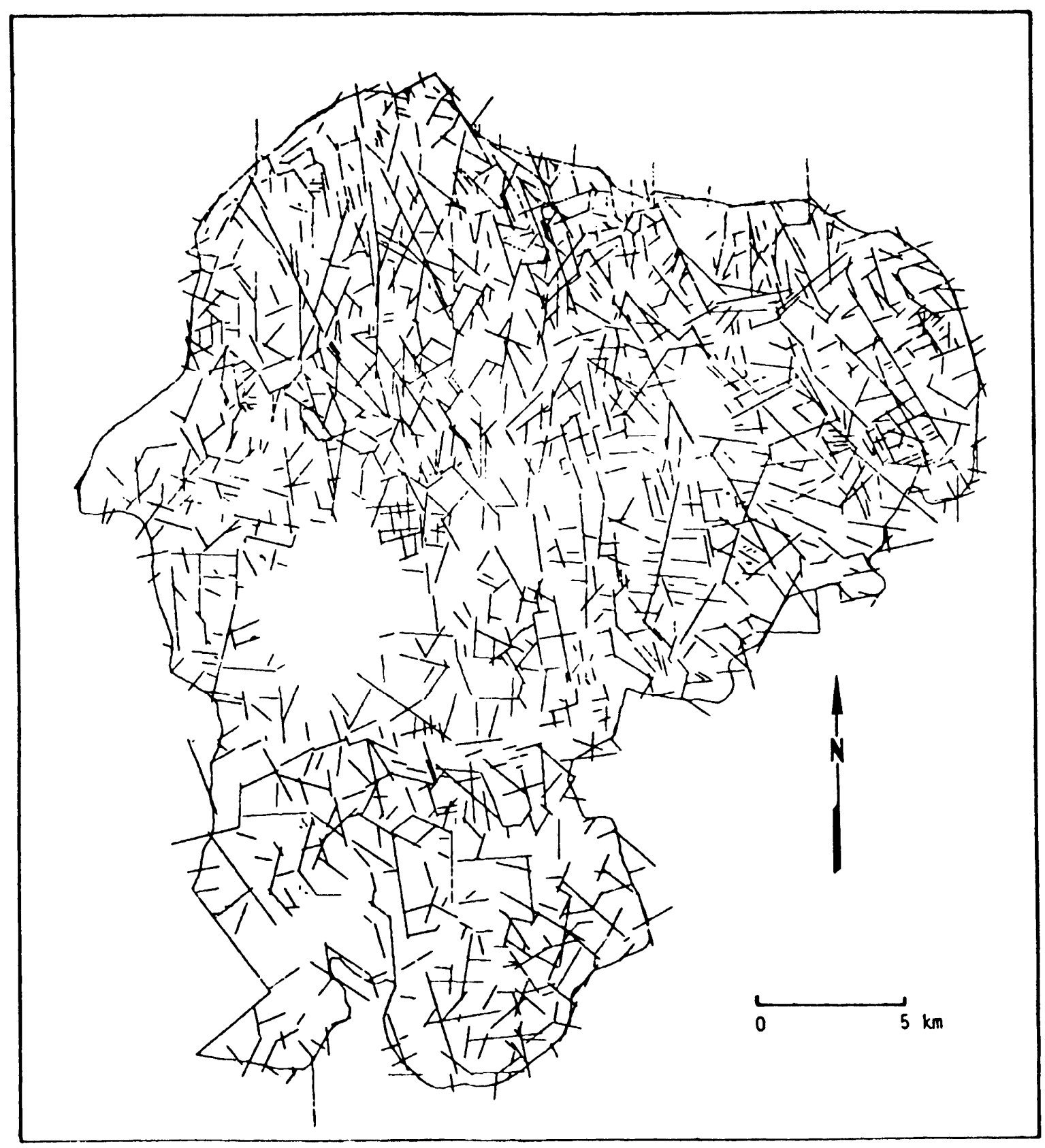

Figure 5. Digitized lineations from the 1:50,000-scale photo mosaic 


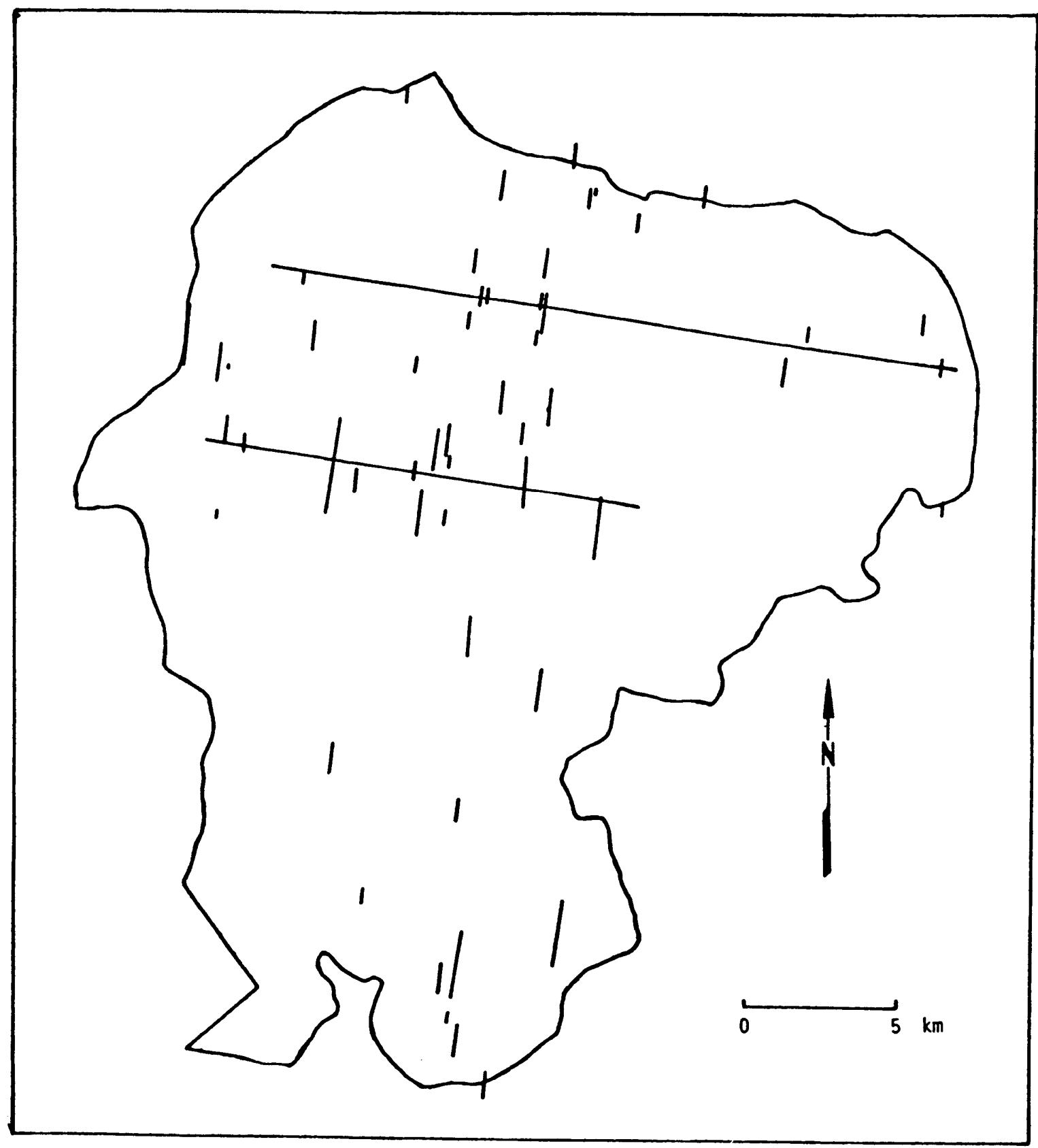

Figure 6. Computer-identified lineation set with typical lines of measurement 


\section{RESULTS}

\section{Orientations}

The rose diagram for the joint orientations measured in the field is shown in Figure 7. Westnorthwest $\left(275-295^{\circ}\right)$ is the most pronounced trend. There are also weaker east-northeast and northnorthwest trends at $40-80^{\circ}$ and $330-340^{\circ}$, respectively. The north-northwest trend contains 29.1 percent of the joints; the east-northeast trend, 21.5 percent; and the north-northwest trend, 13.6 percent.

DARTMOOR. ENGLAND FIELD DATA

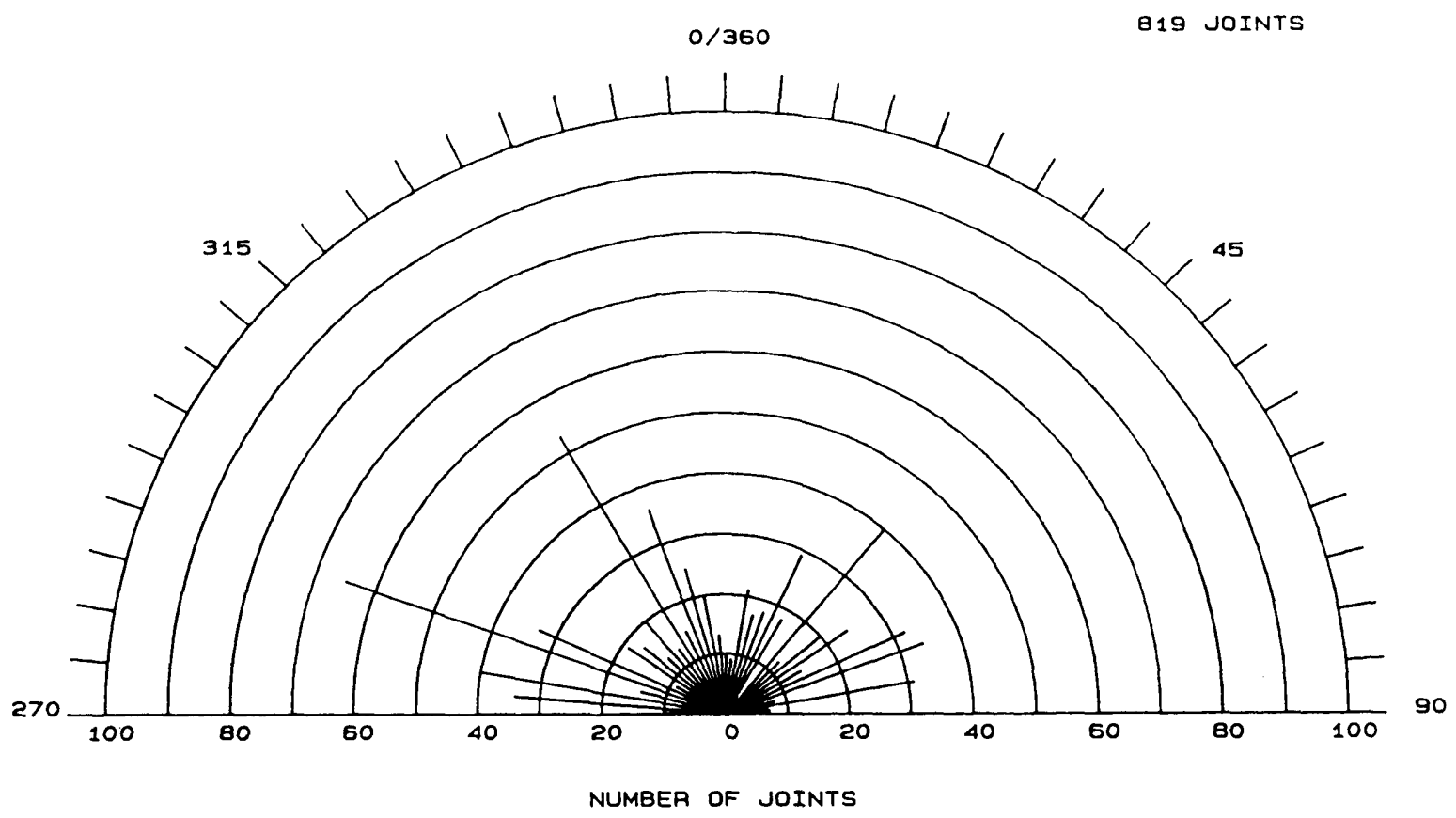

Figure 7. Rose diagram showing vertical joint orientations measured in the field

Figure 8 shows the rose diagrams for the lineations delineated on the two photo mosaics. The most prominent trend on both mosaics is north-northwest, $345-360^{\circ}$, which comprises 15.8 percent of the total, for the 1:50,000-scale lineations (see Figure 8A); and 330-350 ${ }^{\circ}$, which comprises 16.4 percen of the total, for the 1:24,000-scale lineations (see Figure 8B). There are weaker trends to the east northeast and the northwest on both mosaics as well. For the 1:50,000-scale lineations (Figure 8A), thes weaker trends are approximately $60-90^{\circ}\left(21 \%\right.$ of the total) and $315-320^{\circ}(6.7 \%)$; and for the $1: 24,006$ scale lineations (Figure $8 \mathrm{~B})$, they are $45-80^{\circ}\left(25.7 \%\right.$ of the total) and $305-315^{\circ}(8.8 \%)$. The ranges ar wider for the 1:24,000-scale lineations because there are more lineations in this data set. 
DARTMOOA. ENGLAND



Figure 8A. Rose diagram showing orientations of the 1:50,000-scale lineations

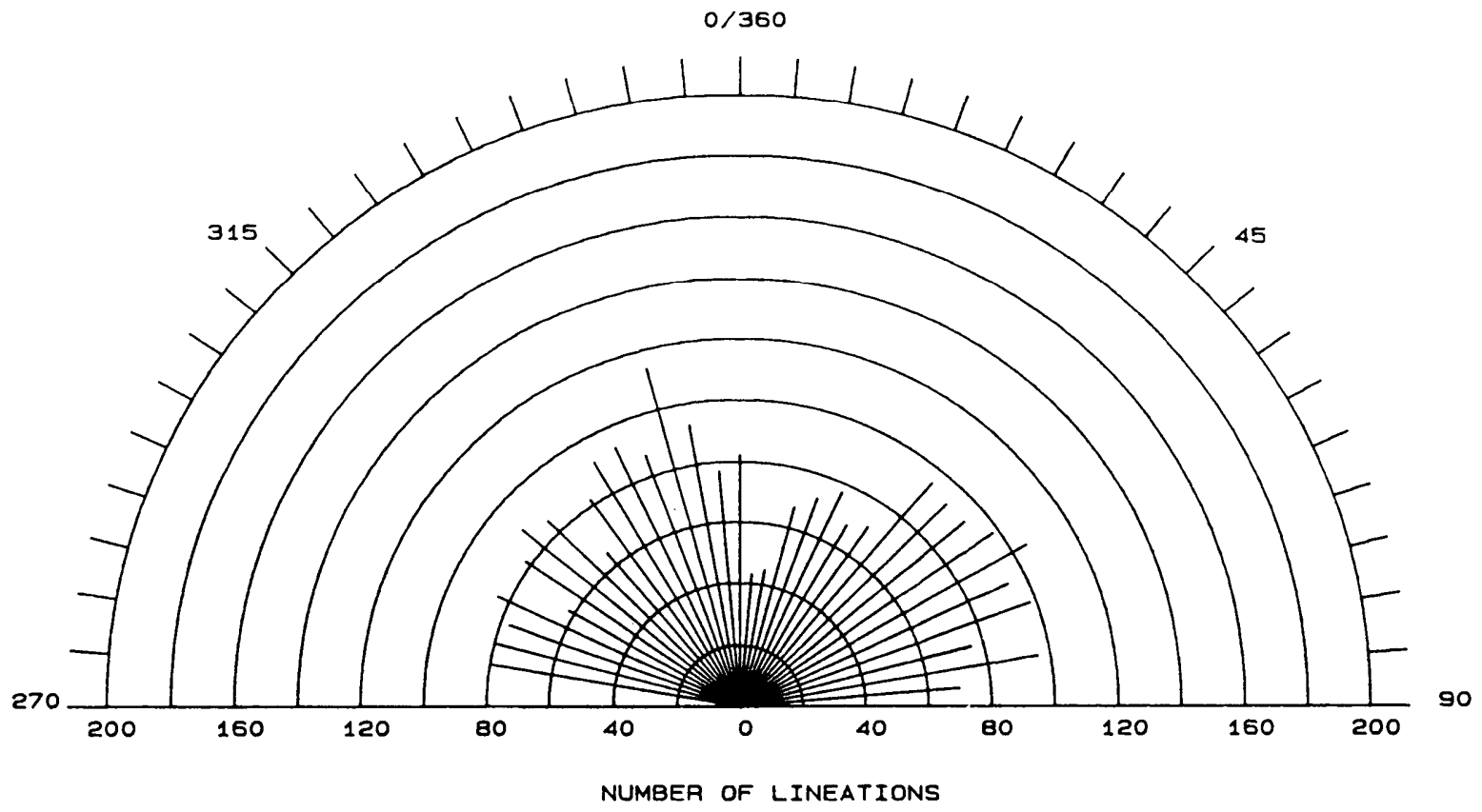

Figure 8B. Rose diagram showing orientations of the 1:24,000-scale lineations 
Because the trends on the two lineation overlays are very similar, it is highly likely that the same sets of lineations are apparent on both image scales. This is supported by the facts that when the spacings are compared by trend, there are no statistically significant differences between groups of lineations, and that correlations between mean spacings for the 5-degree increments are also not significant.

\section{Spacing}

A modal range of $100 \pm 25 \mathrm{~cm}$ best describes the distribution for vertical and steeply-dipping joints measured in outcrop (Figure 9). Although data on horizontal joints were collected, only vertical and steeply-dipping joints are addressed here to facilitate direct comparison to lineation patterns. The distribution is multimodal, with weaker modes at $195-200 \mathrm{~cm}, 300-305 \mathrm{~cm}$, and $425-430 \mathrm{~cm}$.

Figure 10 shows the lineation spacings for both photo mosaics. The histograms are somewhat difficult to interpret because the distributions extend off the high ends of the plots, i.e. some spacings exceed $700 \mathrm{~m}$. This is probably not significant, however, because spacings on histograms where all data plot within the length of the $\mathrm{x}$-axis become increasingly fewer as spacings become wider. The widest spacings also tend to occur singly, not in groups, so it is unlikely that significant information is lost. Disregarding the false modes at $700 \mathrm{~m}$, the modes for both distributions are around $100 \pm 25 \mathrm{~m}$; both distributions are multimodal. Additionally, weaker modes for the 1:50,000-scale lineation distribution are located at $205-210 \mathrm{~m}$ and $495-500 \mathrm{~m}$ (see Figure 10a). In the distribution for the 1:24,000-scale lineations, weaker modes are located at 280-285 m, 310-315 $\mathrm{m}$ and 480-485 m (see Figure 10b).

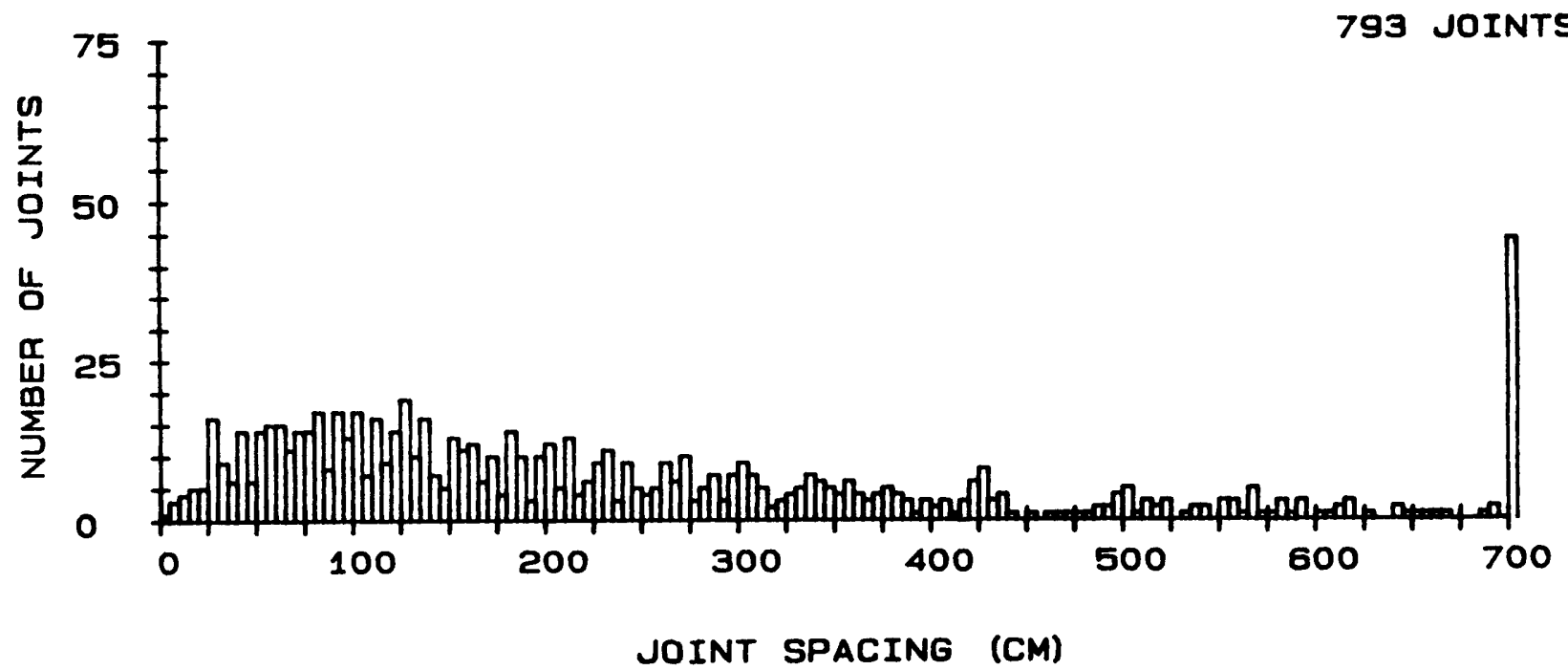

Figure 9. Histogram showing vertical joint spacing frequencies measured in the field 


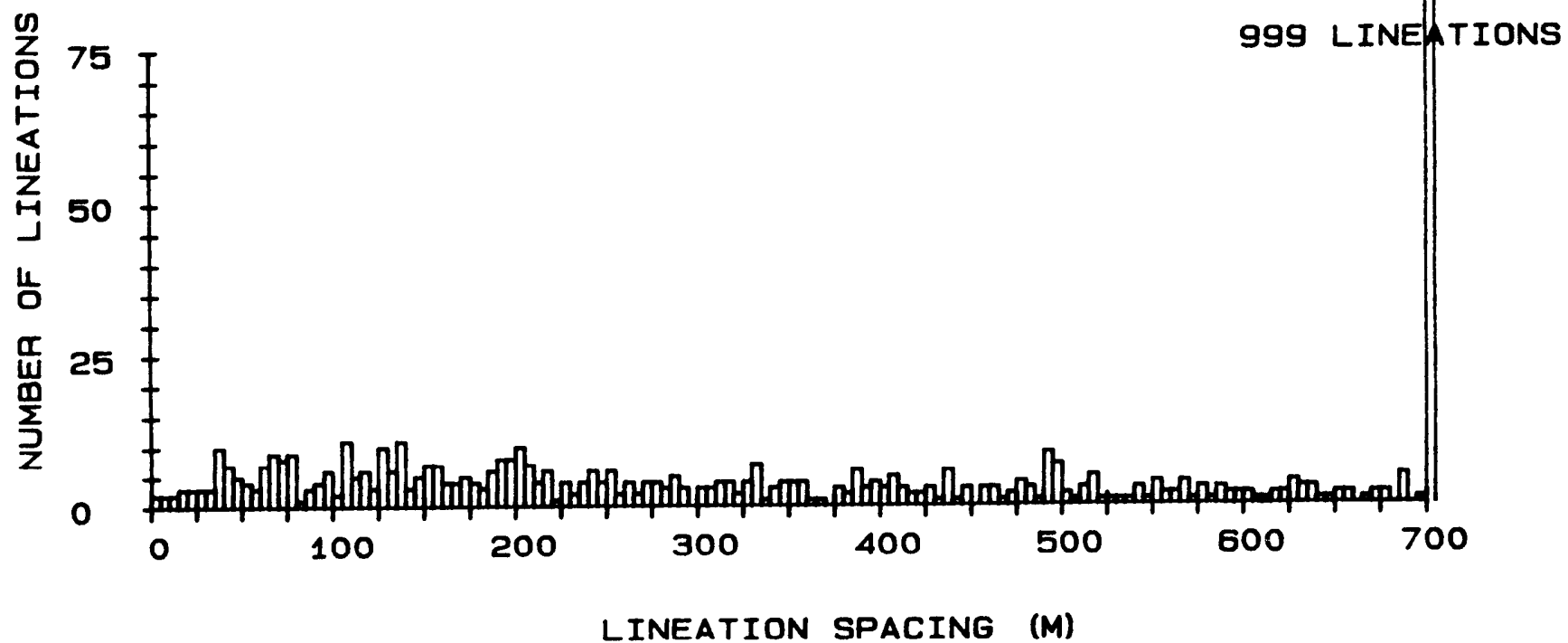

Figure 10A. Histogram showing lineation spacing frequencies for the 1:50,000-scale lineations

DARTMOOR. ENGLAND

SCALE - 1:24.000




0

100

200

300
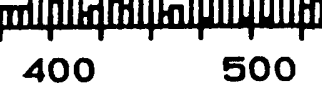

600

LINEATION SPACING (M)

Figure 10B. Histogram showing lineation spacing frequencies for the 1:24,000-scale lineations 


\section{COMPARISON OF LINEATIONS AND JOINT PATTERNS}

\section{Orientations}

The most prominent trend for the lineations is north-northwest and for the joints, it is westnorthwest (Table 1). However, the weaker north-northwest joint trend (330-340 $\left.{ }^{\circ}\right)$ is very similar to the prominent north-northwest lineation trend, and the weak northeast $\left(40-80^{\circ}\right)$ joint trend includes the weak lineation trends, i.e. $60-90^{\circ}$ on the $1: 50,000$-scale mosaic and $45-80^{\circ}$ on the $1: 24,000$-scale mosaic. The prominent west-northwest trend in the field data is present on the lineation rose diagrams, but it is less important than the north-northwest, east-northeast, and northwest trends.

Table 1. Prominent Trends for the Three Data Sets

\begin{tabular}{lrrr} 
& $\begin{array}{c}\text { Ground } \\
\text { Data }\end{array}$ & $\begin{array}{r}1: 24,000 \\
\text { Scale Data }\end{array}$ & $\begin{array}{c}1: 50,000 \\
\text { Scale Data }\end{array}$ \\
\cline { 2 - 3 } & & & \\
$\begin{array}{l}\text { Prominent Orientations } \\
\text { (in degrees) }\end{array}$ & $275-295$ & $330-350$ & $345-360$ \\
$\begin{array}{l}\text { Secondary Orientations } \\
\text { (in degrees) }\end{array}$ & $40-80$ & $45-80$ & $60-90$ \\
$\quad$ & $330-340$ & $305-315$ & $315-320$
\end{tabular}

The north-northwest lineation trend is in agreement with published field data (de la Beche, 1839; Brammall, 1926; Blyth, 1962; and Exley and Stone, 1964; among others). De la Beche (1839), Osman (1928) and Blyth (1962) also noted the east-northeast lineation trend in their field data, but only Brammall (1926) noted both the east-northeast and west-northwest trends. The west-northwest joint trend compared favorably with Worth's (1930) data, and with Ormerod's (1869) and Gerrard's (1978) data as well. ${ }^{1}$ The west-northwest joint trend was noted by Brammall and Harwood (1925) and by Blyth (1962). These published data sets are all much smaller than the ones used in this study.

The prominent trends common to all three data sets identify two regional fracture orientations: east-northeast $\left(40-90^{\circ}\right)$ and north-northwest $\left(330-360^{\circ}\right)$. The prominent west-northwest joint trend (275$\left.295^{\circ}\right)$ compares well with Brammall's $(1926,1928)$ mineralized, Armorican (or Variscan) trend, which is important throughout the Cornubian batholith. Lineations with this trend are present at both photo scales, but the trend is not prominent. These joints may be too closely spaced to be seen at the smaller photo scales. The northwest trend $\left(305-320^{\circ}\right)$, common to both lineation data sets and absent in the field data, may exhibit the opposite characteristics, i.e. the lineations are very long and widely spaced, such that the spacing is so wide that there were too few joints in the set in most locations for it to be measured in the field. It is also likely that the north-northwest trend, so strong on the air photos but less so in the ground data, also consists of very long, widely-spaced fractures, but fractures that are less widely spaced than those that trend northwest.

According to Brammall (1928), trends generated by the Variscan orogeny range from east-west to northwest, a range that includes most of the prominent trends discussed above. Thus it is likely that

\footnotetext{
1 Orientation measurements by Worth and Ormerod are most likely based on magnetic, not true north. Gerrard's data were based on magnetic north. Their data has been corrected so that it can be directly compared with the data presented here, which are based on true north.
} 
many of the joints and lineations on Dartmoor are either primary features or very similar in age to the granite itself, i.e. they could be (1) cooling joints, (2) the result of stresses caused during emplacement, or (3) associated with late-stage hydrothermal activity and/or metasomatism. Durrance et al. (1982) identify the northeast-southwest fractures as Variscan as well. They believe that most of these fractures are associated with the later intrusion of dikes and the major phase of mineralization. The most common trends, northwest and north-northwest, roughly parallel the Lustleigh-Sticklepath fault, a major Tertiary fault that cuts through Dartmoor in the northeast; so it is likely that the joints and the fault have a similar origin and that many of these joints are Tertiary in age (Dearman, 1964). There is some overlap between this Tertiary trend and portions of the Variscan trend, which is in part northwest, so some of the northwest-trending fractures may result from Tertiary reactivation of the older, Variscan trend.

\section{Spacing}

The three frequency distributions were compared using the chi square test and significant differences at the 99 percent level were identified between all three distributions: the field data and the 1:24,000-scale lineations, the field data and the 1:50,000-scale lineations, and the 1:24,000 and 1:50,000scale lineations. This is because spacings between fractures at one scale are necessarily different from those measured at another, owing in part to spatial resolution. Some fractures that can be discerned at larger scales will not be apparent at smaller scales; thus spacings become wider with decreasing scale. Although the spacing distributions are different, all three are multimodal and are skewed to the left side of the histogram to one degree or another. There is a progression from the 1:50,000-scale mosaic to the field data, and to the 1:24,000-scale lineations with respect to curve shape and skewness (see Figures 9 and 10). The pattern appears to become more clearly defined in this order. As expected, mean spacing decreases with increasing scale: $1487.3 \mathrm{~m}$ for the 1:50,000-scale mosaic, $961.4 \mathrm{~m}$ for the 1:24,000-scale mosaic, and $2.6 \mathrm{~m}$ for the field data.

These results suggest that the lineations are fractures and that the sets visible on the ground are also apparent on both scales of photos. The fractures distinguishable at the different scales - ground, $1: 24,000$ and 1:50,000 - are different individuals, with the longer and more widely-spaced members of each set becoming visible as scale decreases. The modes are virtually at the same points on the $x$-axis for all three histograms, i.e. at about $100 \pm 25$ (see Table 2). There is also similarity between the weaker modes: the $195-200 \mathrm{~cm}$ mode in the field data compares well with the $205-210 \mathrm{~m}$ mode in the 1:50,000-scale distribution; and the 300-305 cm mode in the field data, with the $310-315 \mathrm{~m}$ mode in the 1:24,000-scale distribution. In addition, the $480-485 \mathrm{~m}$ mode in the 1:24,000-scale distribution compares favorably with the $495-500 \mathrm{~m}$ mode in the $1: 50,000$-scale distribution.

Table 2. Modal Spacing for the Three Data Sets

\begin{tabular}{lccc} 
& $\begin{array}{c}\text { Ground } \\
\text { Data }\end{array}$ & $\begin{array}{c}1: 24,000 \\
\text { Scale Data }\end{array}$ & $\begin{array}{c}1: 50,000 \\
\text { Scale Data }\end{array}$ \\
\cline { 2 - 3 } & & & \\
$\begin{array}{l}\text { Modal Category } \\
\text { (cm,m,m) }\end{array}$ & $125-130$ & $85-90$ & $110-115$ \\
$\begin{array}{l}\text { Secondary Modal Categories } \\
\text { (cm,m,m) }\end{array}$ & $195-200$ & $280-285$ & $205-210$ \\
& $300-305$ & $310-315$ & $495-500$ \\
& $425-430$ & $480-485$ &
\end{tabular}


Because the modes for all distributions are so similar, it is likely that the lineations are joints, rather than faults. Further support for this is provided by the geological maps of Dartmoor. Few of the lineations are delineated as faults and it is highly likely that any faults that exist would have been identified over the past 150 years of mining and other geological investigations. The lineations are the longest members of any given set as well as the most widely spaced. Different members of the same joint sets are apparent at the different scales; decreasing scale merely allows these otherwise "invisible," very long, and widely-spaced joints to be seen.

\section{CONCLUSIONS}

Lineations are interpreted to be very long, widely-spaced joints that are parts of joint sets identified in the field. Smaller scale merely allows the more widely-spaced and longer members of a given set to be seen. It is thus likely that all three data sets (field data, 1:24,00-scale lineations, and 1:50,000-scale lineations) belong to the same population of joints, or in other words, identification of joint sets is scale independent. This is supported, first, by the overall similarity in prominent trends between the three data sets. Three data sets are similar, but not identical. Of the nine trends listed, six are common to all three data sets, and two additional trends are similar in two of the data sets. Second, although there is at least a magnitude of difference between the joint and lineation spacings, there is also much similarity between the modes, which tend to occur close to even 100 's. Joint spacing may thus be periodic.

Although this study of fracture patterns in the Dartmoor Granite shows that there are quantifiable relations between the data collected in the field and two-dimensional data delineated on air photos, it does not address the three-dimensional problem: how can these data be used to construct and understand threedimensional subsurface fracture networks?

The scale independence of the fracture patterns on Dartmoor suggests they may be fractal in nature (Malinverno, 1991). Barton (1991) lists a number of fractal analyses of fracture-trace maps, all of which are fractal. Although most of these analyses were done on volcanic rocks, two areas of granitic rocks are listed. Their fractal dimensions are 1.50 and 1.52. A fractal analysis has not yet been completed for the Dartmoor data, but the lineations from both photo mosaics have fractal distributions (the dimension has not yet been determined).

As fractal dimension increases by a factor of 1 for each dimension, the fractal dimensions of three-dimensional fracture networks (subsurface?) in the two granitic areas mentioned above would be 2.50 and 2.52, respectively. Accordingly, fractal dimensions determined using two-dimensional data can also form the basis for realistic simulations of subsurface fracture networks (Barton, 1991). Fractal analyses may thus provide the predictive link between fracture patterns identified in the field and on remotely-sensed imagery and three-dimensional subsurface fracture networks. 


\section{REFERENCES}

Bandat, H.F., von, 1962, Aerogeology: Gulf Publishing Co., Houston, TX.

Barton, C.C., 1991, Fractal analysis of the scaling and spatial clustering of fractures: In C.C Barton, P.R. LaPointe and A. Malinverno (eds), Geological Society of America Short Course Manual on Fractals and Their Use in Earth Sciences, pp. 204-279.

De La Beche, H.T., 1839, Report on the geology of Cornwall, Devon, and West Somerset: Longmans, London, pp 156-192, 270-282.

Belcher, D.J., Ta Liang, Fallon, G.J., Costello, R.B., Hodge, R.J., Ladenheim, H.C., Lueder, D.R. and Mollard, J.D., 1951, A Photo Analysis Key for the Determination of Ground Conditions, vol. 3, Igneous and Metamorphic Rocks: Cornell University School of Engineering, for the Amphibious Branch, Office of Naval Research, U.S. Naval Photographic Interpretation Center, Ithaca, New York.

Bevan, T.G. and Hancock, P.L., 1986, A late Cenozoic regional mesofracture system in southern England and northern France: Journal of the Geological Society of London, vol. 143, pp 355-362.

Blyth, F.G.H., 1962, The structure of the north-eastern tract of the Dartmoor granite: Quarterly Journal of the Geological Society of London, vol. 118, pp 435-453.

Brammall, A., 1926, The Dartmoor granite: Proceedings of the Geologist's Association, vol. 37, pp 251-282.

, 1928, Notes on fissure-phenomena and lode trend in the Dartmoor granite: Royal Geological Society of Cornwall, Transactions, vol. 16, pp 15-27.

Brammall, A. and Harwood, H.F., 1925, Tourmalinization in the Dartmoor granite: Mineralogical Magazine, vol. 20, pp 319-330.

Brown, C.W., 1961, Comparison of joints, faults and airphoto linears: American Association of Petroleum Geologists Bulletin, vol. 45, pp 1888-1892.

Darbyshire, D.P.F. and Shepherd, T.J., 1985, Chronology of granite magmatism and associated mineralization, SW England: Journal of the Geological Society of London, vol. 142, pp 1159-1177.

Dearman, W.R., 1964, Dartmoor, its geological setting: In I.G. Simmons, (ed), Dartmoor Essays, Devonshire Association for the Advancement of Science, Literature and Art, Exeter, pp 1-29

Durrance, E.M., Bromley, A.V., Bristow, C.M., Heath, M.J. and Penman, J.M., 1982, Hydrothermal circulation and post-magmatic changes in granites of south-west England: Proceedings of the Ussher Society, vol. 5, pp 304-320.

Exley, C.S. and Stone, M., 1964, The granitic rocks of southwest England: In K.F.G. Hosking, and G.J. Shrimpton, (eds), Present Views of Some Aspects of the Geology of Cornwall and Devon, Royal Geological Society of Cornwall, Penzance, pp 131-184. 
Gerrard, A.J.W., 1974, The geomorphological importance of jointing in the Dartmoor granite: In E. H. Brown, and R, S. Waters, (eds), Progress in Geomorphology, Institute of British Geographers, Special Publication No. 7, pp 39-50.

, 1978, Tors and granite landforms of Dartmoor and eastern Bodmin Moor: Proceedings of the Ussher Society, vol. 4, pp 204-210.

, 1988, Rocks and Landforms: Unwin Hyman, London.

Lukes, G.E., 1981, Computer-assisted photo interpretation research at the United States Army Engineer Topographic Laboratories (USAETL): Techniques and Applications of Image Understanding, Proceedings of SPIE, International Society for Optical Engineering, vol. 281, pp 85-94.

Malinverno, A. 1991, untitled: In C. C. Barton, P. R. LaPointe, and A. Malinverno, (eds), Geological Society of America Short Course Manual on Fractals and Their Use in Earth Sciences, pp. 1-108.

Mohammad, M.R., 1986, Jointing and air photo lineations in Jurassic limestone formations of Al-Adirab area, Tuwayq Mountain, adjacent to Ar-Riyadh, Saudi Arabia: In V. Gardiner. (ed), International Geomorphology, Part II, pp 359-365.

Osman, C.W., 1928, The granites of the Scilly Isles and their relation to the Dartmoor granites: Quarterly Journal of the Geological Society of London, vol. 84, pp 259-292.

Ormerod, G.W., 1869, On some of the results arising from the bedding, joints, and spheroidal structure of the granite on the eastern side of Dartmoor, Devonshire: Quarterly Journal of the Geological Society of London, vol. 25, pp 273-280.

Rinker, J.N., 1974, An application of air photo analysis to a cave location study: Proceedings of the American Society of Photogrammetry 40th Annual Meeting (St. Louis, Missouri), pp 281-289.

Rinker, J.N. and Corl, P.A., 1984, Air photo analysis, photo interpretation logic, and feature extraction: U.S. Army Engineer Topographic Laboratories, Ft. Belvoir, Virginia, ETL-0329.

Segall, P. and Pollard, D.D., 1983, From joints and faults to photo-lineations: In I. Ramberg, and R. H. Gabrielson (eds), Proceedings of the 4th International Conference on Basement Tectonics (Norway), Basement Tectonics Committee Inc., Denver, pp 11-20.

Thorp, M.B., 1967, Joint patterns and the evolution of landforms in the Jarawa granite massif, northern Nigeria: In R. W. Steel, and R, Lawton, (eds), Liverpool Essays in Geography, Longmans, London, pp 65-83.

, 1967b, Closed basins in Younger Granite Massifs, northern Nigeria: Zeitschrift fur Geomorphology, vol. 11, pp 459-480.

Way, D.S., 1973, Terrain Analysis, a guide to site selection using aerial photographic interpretation, 2nd edition: McGraw-Hill Book Co., New York. 
Worth, R.H., 1930, Address of the President: The physical geography of Dartmoor: Transactions of the Devonshire Association, vol. 62, pp 49-115. 